\title{
Pengaruh self concept terhadap kemampuan berpikir tingkat tinggi mata pelajaran matematika siswa kelas VIII F SMPN 1 Mataram
}

\section{Sri Radiatun Wahida1, Baidowi², Ulfa Lu'luilmaknun², Muhammad Turmuzi ${ }^{2}$}

\author{
${ }^{1}$ Mahasiswa Pendidikan Matematika, FKIP, Universitas Mataram, Mataram \\ ${ }_{2}^{2}$ Pendidikan Matematika, FKIP, Universitas Mataram, Mataram
}

radiyatunnadya@gmail.com

Diterima: 09-07-2021 ; Direvisi: 31-12-2021 ; Dipublikasi: 31-12-2021

\begin{abstract}
This study aims to describe and determine the effect of self-concept on higher-order thinking skills of class VIII SMPN 1 Mataram in the academic year 2020/2021. This type of research is included in ex post facto research, with a sample of 32 students of class VIII F SMPN 1 Mataram in the 2020/2021 academic year. Students fill out and complete self-concept questionnaires and test questions for higher order thinking skills. The results showed that (1) Self-concept owned by $3.13 \%$ students was categorized as very good, $21.87 \%$ students were in good category, $62.5 \%$ students were in quite good category, and $12.5 \%$ students were in low category. Meanwhile, for higher order thinking skills, there are $3.13 \%$ of students in very good category, $21.87 \%$ of students in good category, $62.5 \%$ of students in good enough category, $9.37 \%$ of students in poor category and $3,13 \%$ of students in the very poor category. (2) There is an effect of self concept on higher order thinking ability with regression equation $\mathrm{Y}=1.283+0.787 \mathrm{X}$.
\end{abstract}

Keywords: self concept; higher order thinking; mathematics

\begin{abstract}
Abstrak
Penelitian ini bertujuan untuk mendeskripsikan dan mengetahui pengaruh self concept terhadap kemampuan berpikir tingkat tinggi siswa kelas VIII SMPN 1 Mataram tahun ajaran 2020/2021. Jenis penelitian ini termasuk dalam penelitian ex post facto, dengan sampel sebanyak 32 orang siswa kelas VIII F SMPN 1 Mataram tahun ajaran 2020/2021. Siswa mengisi dan menyelesaikan angket self concept serta soal tes kemampuan berpikir tingkat tinggi. Hasil penelitian menunjukkan bahwa (1) Self concept yang dimiliki siswa 3,13\% dikategorikan sangat baik, 21,87\% siswa kategori baik, 62,5\% siswa kategori cukup baik, dan 12,5\% siswa kategori rendah. Sedangkan untuk kemampuan berpikir tingkat tinggi terdapat $3,13 \%$ siswa dengan kategori sangat baik, 21,87\% siswa kategori baik, $62,5 \%$ siswa kategori cukup baik, 9,37\% siswa kategori kurang dan 3,13\% siswa kategori kurang sekali. (2) Terdapat pengaruh self concept terhadap kemampuan berpikir tingkat tinggi dengan persamaan regresi $\mathrm{Y}=1,283+0,787 \mathrm{X}$.
\end{abstract}

Kata Kunci: self concept; berpikir tingkat tinggi; matematika

\section{PENDAHULUAN}

Pada awal abad ke-20, pendidikan fokus pada pencapaian keterampilan literasi dasar: membaca, menulis, dan menghitung. Sebagian besar sekolah tidak mengajarkan siswa untuk berpikir dan membaca secara kritis atau untuk memecahkan masalah yang kompleks (Bransford et al., 2004). Abad 21, paradigma pendidikan mulai bergeser. Di Indonesia, melalui kurikulum 2013 yang telah mengakomodasi keterampilan abad 21, pendidikan dilaksanakan untuk mengasah; (1) kreativitas dan inovasi (creativity and 
innovation skills); (2) berpikir kritis dan pemecahan masalah (critical thinking and problem-solving); (3) kemampuan berkomunikasi dan berkolaborasi (communication and collaboration skills); (4) literasi teknologi informasi dan komunikasi (information and communication technology literacy); (5) belajar kontekstual (contextual learning skills), dan (6) literasi media dan informasi (information and media literacy skills) (Gradini, 2019). Kemampuan tersebut merupakan tuntutan abad 21, yang mana adalah keterampilan berpikir tingkat tinggi (HOTS) (Gradini, 2019).

Peraturan Menteri Pendidikan dan Kebudayaan Nomor 35 Tahun 2018 tentang Perubahan atas Peraturan Menteri Pendidikan dan Kebudayaan Nomor 58 Tahun 2014 tentang Kurikulum 2013 Sekolah Menengah Pertama/Madrasah Tsanawiyah pada lampiran I menyatakan bahwa salah satu dasar penyempurnaan kurikulum adalah adanya tantangan eksternal, antara lain terkait dengan arus globalisasi dan berbagai isu yang terkait dengan masalah lingkungan hidup, kemajuan teknologi dan informasi, kebangkitan industri kreatif dan budaya, dan perkembangan pendidikan di tingkat internasional.

Keterlibatan Indonesia dalam Programme for International Student Assessment (PISA) merupakan upaya pemerintah melihat sejauh mana pendidikan di negara kita berkembang dibanding negara-negara lain. PISA merupakan suatu studi bertaraf internasional yang diselenggarakan oleh Organization for Economic Cooperation and Development (OECD) yang mengkaji kemampuan berpikir siswa pada rentang usia 15 tahun yang diikuti oleh beberapa negara peserta, termasuk Indonesia (Kurniati et al., 2016). Namun hasil studi PISA Indonesia tahun 2018 menunjukkan bahwa kemampuan siswa Indonesia dalam membaca, hanya meraih skor rata-rata yakni 371 dengan ratarata skor OECD 487, sedangkan untuk skor rata-rata matematika 379 dengan skor rata-rata OECD 489. Hasil tersebut tidak jauh lebih baik dari PISA sebelumnya pada tahun 2015 (OECD, 2019).

Hasil wawancara dengan guru matematika kelas VIII di SMPN 1 Mataram, dikatakan bahwa sekolah belum maksimal dalam mengukur kemampuan berpikir tingkat tinggi siswa. Ditambah saat ini situasi pandemi yang mengharuskan siswa belajar dirumah. Pemberian soal yang memerlukan kemampuan berpikir tingkat tinggi dirasa sulit bagi siswa. Pemikiran tingkat tinggi dirasa hanya cocok untuk siswa berprestasi, sedangkan siswa berprestasi rendah, yang hampir tidak bisa menguasai kemampuan dasar, tidak akan mampu menangani tugas-tugas tersebut. Namun dikatakan pula bahwa mengukur kemampuan berpikir tingkat tinggi sangatlah penting dan perlu diterapkan. Hanya saja untuk mencapai hal tersebut tidaklah mudah.

Salah satu upaya yang dapat berpengaruh terhadap hasil belajar siswa adalah aspek psikologis. Aspek psikologis dalam pembelajaran berkaitan dengan minat, sikap, motivasi dan kreativitas siswa. Aspek psikologis dapat memberikan kontribusi terhadap keberhasilan seseorang dalam menyelesaikan tugas akademik dengan baik. Aspek psikologis yang dimaksud adalah self concept (Rahman, 2012). Pada dasarnya 
setiap individu atau siswa memiliki self concept, baik positif atau negatif. Self concept yang positif sangat penting bagi kemajuan, perkembangan dan prestasi siswa kedepannya (Sriyanti, 2009).

Hasil studi PISA tahun 2018 menunjukkan bahwa 89\% siswa di Indonesia biasanya dapat menyelesaikan atau menemukan jalan keluar terkait permasalahan yang sulit, sedangkan 59\% siswa ketika mereka gagal, mereka khawatir dengan apa yang oranglain pikirkan dan anak perempuan akan menunjukkan rasa takut yang lebih besar terhadap kegagalan daripada anak laki-laki (OECD, 2019).

Oleh karena itu, peneliti tertarik meneliti "Pengaruh Self Concept Terhadap Kemampuan Berpikir Tingkat Tinggi Mata Pelajaran Matematika Siswa Kelas VIII SMPN 1 Mataram Tahun Ajaran 2020/2021".

\section{METODE PENELITIAN}

Penelitian ini menggunakan metode penelitian ex post facto dengan teknik korelasi untuk mencari hubungan dua variabel atau lebih. Variabel bebas dalam penelitian ini adalah self concept dan variabel terikat adalah kemampuan berpikir tingkat tinggi. Populasi dalam penelitian ini adalah siswa kelas VIII SMPN 1 Mataram tahun ajaran 2020/2021, sedangkan sampel adalah siswa kelas VIII F yang berjumlah 32 orang, dimana pengambilan sampel dilakukan secara cluster random sampling.

Untuk memperoleh data dalam penelitian ini digunakan instrumen angket self concept dan soal tes kemampuan berpikir tingkat tinggi. Namun sebelum data hasil penelitian dari instrumen angket self concept digunakan, dilakukan transformasi data dari data ordinal ke data interval dengan menggunakan Method of Successive Interval (MSI).

Hasil penelitian diperoleh melalui perhitungan menggunakan analisis inferensial, yaitu analisis korelasi dan analisis regresi sederhana. Analisis korelasi pada penelitian ini menggunakan analisis korelasi pearson product moment, yang kemudian dilanjutkan dengan uji $t$ untuk mengetahui keberartian koefisien korelasi. Setelah itu melakukan analisis regresi sederhana serta menguji keberartian regresi menggunakan uji $F$.

\section{HASIL DAN PEMBAHASAN}

Hasil analisis deskriptif self concept siswa kelas VIII SMPN 1 Mataram tahun ajaran 2020/2021 dapat dilihat pada Tabel 1. Hasil analisis deskriptif kemampuan berpikir tingkat tinggi siswa kelas VIII SMPN 1 Mataram tahun ajaran 2020/2021 dapat dilihat pada Tabel 2. Uji prasyarat dalam penelitian ini yaitu uji normalitas dan uji linearitas. Uji Normalitas dilakukan dengan menggunakan uji Kolomogorov-Smirnov, hasil perhitungannya dapat dilihat pada Tabel 3. 
Tabel 1. Hasil Analisis Deskriptif Self Concept

\begin{tabular}{cccc}
\hline Interval & Banyak siswa & Persentase (\%) & Kategori \\
\hline $72,50<\mathrm{X} \leq 90,00$ & 1 & $3,13 \%$ & Sangat Baik \\
$60,83<\mathrm{X} \leq 72,50$ & 7 & $21,87 \%$ & Baik \\
$49,16<\mathrm{X} \leq 60,83$ & 20 & $62,5 \%$ & Cukup Baik \\
$37,49<\mathrm{X} \leq 49,16$ & 4 & $12,5 \%$ & Kurang \\
$19,99 \leq \mathrm{X} \leq 37,49$ & 0 & $0 \%$ & Kurang Sekali \\
\hline
\end{tabular}

Tabel 2. Hasil Analisis Deskriptif Kemampuan Berpikir Tingkat Tinggi

\begin{tabular}{cccc}
\hline Interval & Banyak siswa & Persentase (\%) & Kategori \\
\hline $67,5<\mathrm{Y} \leq 90$ & 1 & $3,13 \%$ & Sangat Baik \\
$52,5<\mathrm{Y} \leq 67,5$ & 7 & $21,87 \%$ & Baik \\
$37,5<\mathrm{Y} \leq 52,5$ & 20 & $62,5 \%$ & Cukup Baik \\
$22,5<\mathrm{Y} \leq 37,5$ & 3 & $9,37 \%$ & Kurang \\
$0 \leq \mathrm{Y} \leq 22,5$ & 1 & $3,13 \%$ & Kurang Sekali \\
\hline
\end{tabular}

Tabel 3. Hasil Perhitungan Uji Normalitas

One-Sample Kolmogorov-Smirnov Test

\begin{tabular}{llr}
\multicolumn{3}{c}{ One-Sample Kolmogorov-Smirnov Test } \\
\hline & & \multicolumn{1}{c}{$\begin{array}{c}\text { Unstandardized } \\
\text { Residual }\end{array}$} \\
\hline $\mathrm{N}$ & & 32 \\
\hline Normal Parameters & & \multicolumn{2}{c}{3} \\
& Mean & .0000000 \\
\cline { 2 - 3 } & Std. & 10.16803929 \\
\hline Most Extreme & Deviation & .123 \\
\cline { 2 - 3 } Differences & Absolute & .123 \\
\cline { 2 - 3 } & Positive &. .069 \\
\cline { 2 - 3 } & Negative & .697 \\
\hline Test Statistic & & .717 \\
\hline Asymp. Sig. (2-tailed) & &
\end{tabular}

a. Test distribution is Normal.

Berdasarkan Tabel 3, nilai signifikansi (Asymp. Sig. (2-tailed)) sebesar 0,717; dimana nilai signifikansi tersebut $>0,05$. Berdasarkan hal tersebut maka data berasal dari populasi yang berdistribusi normal. Kemudian untuk hasil perhitungan uji linearitas dapat dilihat pada Tabel 4.

Tabel 4. Hasil Perhitungan Uji Linearitas

\begin{tabular}{|c|c|c|c|c|c|c|c|c|}
\hline \multicolumn{9}{|c|}{ ANOVA Table } \\
\hline & & & & $\begin{array}{l}\text { Sum of } \\
\text { squares }\end{array}$ & $\mathrm{df}$ & $\begin{array}{c}\text { Mean } \\
\text { square }\end{array}$ & $\mathrm{F}$ & Sig. \\
\hline \multirow{5}{*}{$\begin{array}{l}\text { Kemampuan } \\
\text { Berpikir } \\
\text { tingkat } \\
\text { tinggi * Self } \\
\text { Concept }\end{array}$} & Between & \multicolumn{2}{|l|}{ (Combined) } & 4013.219 & 30 & 133.774 & 267.548 & .048 \\
\hline & & Linearity & \multirow[b]{2}{*}{ from } & 808.659 & 1 & 808.659 & $1.617 \mathrm{E} 3$ & .016 \\
\hline & & $\begin{array}{l}\text { Deviation } \\
\text { Linearity }\end{array}$ & & 3204.560 & 29 & 110.502 & 221.004 & 0.53 \\
\hline & Within G & oups & & .500 & 1 & .500 & & \\
\hline & Total & & & 4013.719 & 31 & & & \\
\hline
\end{tabular}


Berdasarkan Tabel 4, diperoleh nilai signifikansi pada Deviation from Linearity sebesar 0,053; dimana nilai signifikansi tersebut $>0,05$. Berdasarkan hal tersebut maka dapat disimpukan bahwa terdapat hubungan yang linear antara self concept dan kemampuan berpikir tingkat tinggi. Kedua variabel memiliki hubungan yang linear, maka kuatnya hubungan antara self concept dan kemampuan berpikir tingkat tinggi dapat dilihat pada koefisien korelasi $(R)$ yang ditampilkan pada Tabel 5.

Tabel 5. Hasil Perhitungan Koefisien Korelasi

\begin{tabular}{ccccc}
\multicolumn{2}{l}{ Model Summary } \\
Model & $\mathrm{R}$ & $\begin{array}{c}\mathrm{R} \\
\text { Square }\end{array}$ & $\begin{array}{c}\text { Adjusted R } \\
\text { Square }\end{array}$ & $\begin{array}{c}\text { Std. Error of } \\
\text { the Estimate }\end{array}$ \\
\hline 1 & $.449^{\mathrm{a}}$ & .201 & .175 & 10.33612 \\
\hline
\end{tabular}

a. Predictors: (Constant), Self Concept

b. Dependent Variabel: Kemampuan Berpikir Tingkat Tinggi

Berdasarkan Tabel 5, diperoleh koefisien korelasi $(R)$ sebesar 0,449. Maka hubungan self concept dan kemampuan berpikir tingkat tinggi siswa SMPN 1 Mataram tahun ajaran 2020/2021 termasuk dalam tingkat hubungan yang cukup kuat. Selanjutnya untuk mengetahui ada atau tidaknya hubungan yang signifikan self concept terhadap kemampuan berpikir tingkat tinggi dapat dilihat pada Tabel 6 .

Tabel 6. Hasil Analisis Regresi Sederhana dan Perhitungan Uji $t$

\begin{tabular}{|c|c|c|c|c|c|c|}
\hline \multicolumn{7}{|c|}{ Coefficients a } \\
\hline \multirow{2}{*}{\multicolumn{2}{|c|}{ Model }} & \multicolumn{2}{|c|}{$\begin{array}{l}\text { Unstandardized } \\
\text { Coefficients }\end{array}$} & \multirow{2}{*}{$\begin{array}{c}\begin{array}{c}\text { Standardized } \\
\text { Coefficients }\end{array} \\
\text { Beta } \\
\end{array}$} & \multirow[b]{2}{*}{$t$} & \multirow[b]{2}{*}{ Sig. } \\
\hline & & B & Std. Error & & & \\
\hline 1 & (Constant) & 1.283 & 16.209 & & .079 & .973 \\
\hline & Self Concept & .787 & .286 & .449 & 2.751 & .010 \\
\hline
\end{tabular}

a. Dependent Variable: Kemampuan Berpikir Tingkat Tinggi

Berdasarkan hasil perhitungan data pada Tabel 6, diperoleh t hitung sebesar 2,751 dan nilai t tabel pada taraf signifikansi $5 \%$ dengan derajat kebebasan dk $(\mathrm{N}-2)=30$ adalah 2,042. Berdasarkan hal tersebut maka $t$ hitung $>\mathrm{t}$ tabel dan nilai sig. $\leq 0,05$ yang berarti Ho ditolak, dapat disimpulkan bahwa terdapat hubungan yang signifikan self concept terhadap kemampuan berpikir tingkat tingi.

Berdasarkan Tabel 6, diperoleh pula nilai $a=1,283$ dan nilai $b=0,787$ sehingga diperoleh persamaan regresinya $Y=1,283+0,787 X$. Kemudian untuk mengetahui keberartian koefisien regresi maka dilakukan uji $F$, hasil perhitungannya dapat dilihat pada Tabel 7.

Berdasarkan Tabel 7, diperoleh nilai $\mathrm{F}$ hitung $=7,569$ dan nilai $\mathrm{F}$ tabel pada taraf signifikansi $5 \%$ dengan derajat kebebasan pembilang $\left(\mathrm{dk}_{1}\right)=1$ dan penyebut $\left(\mathrm{dk}_{2}\right)=30$ adalah 4,17. Karena nilai $\mathrm{F}$ hitung $>\mathrm{F}$ tabel dan nilai sig. $\leq 0,05$, maka koefisien regresi dari persamaan regresi $\mathrm{Y}=1,283+0,787 \mathrm{X}$ dapat digunakan untuk memprediksi kemampuan berpikir tingkat tinggi $(\mathrm{Y})$ yang dipengaruhi oleh self concept $(\mathrm{X})$. 
Tabel 7. Hasil Perhitungan Uji $F$

\begin{tabular}{|c|c|c|c|c|c|c|}
\hline \multicolumn{7}{|c|}{ ANOVA $^{b}$} \\
\hline Model & & $\begin{array}{c}\text { Sum of } \\
\text { Squares }\end{array}$ & Df & Mean Square & $\mathrm{F}$ & Sig. \\
\hline \multirow[t]{3}{*}{1} & Regression & 808.659 & 1 & 808.659 & 7.569 & $.010^{\mathrm{a}}$ \\
\hline & Residual & 3205.060 & 30 & 106.835 & & \\
\hline & Total & 4013.719 & 31 & & & \\
\hline
\end{tabular}

a. Predictors: (Constant), Self Concept

b. Dependent Variable: Kemampuan Berpikir Berpikir Tingkat Tinggi

Hasil analisis statistik deskriptif untuk self concept siswa kelas VIII SMPN 1 Mataram tahun ajaran 2020/2021 menunjukkan bahwa terdapat 3,13\% siswa dikategorikan sangat baik, 21,87\% siswa kategori baik, 62,5\% siswa kategori cukup baik, dan 12,5\% siswa kategori rendah. Dari hasil analisis statistik deskriptif self concept tersebut dapat disimpulkan bahwa secara umum sebagian besar siswa kelas VIII SMPN 1 Mataram memiliki self concept yang baik atau positif.

Selanjutnya, hasil analisis deskriptif untuk kemampuan berpikir tingkat tinggi siswa kelas VIII SMPN 1 Mataram tahun ajaran 2020/2021 menunjukkan bahwa 3,13\% siswa dikategorikan sangat baik, 21,87\% siswa kategori baik, 62,5\% siswa kategori cukup baik, 9,37\% siswa kategori kurang dan 3,13\% siswa kategori kurang sekali. Berdasarkan hasil analisis deskriptif dari kedua variabel, self concept siswa berbanding lurus dengan kemampuan tingkat tinggi, dimana kedua variabel dapat digolongkan dalam kategori baik yang mengindikasikan adanya hubungan antara kedua variabel.

Berdasarkan hasil perhitungan menggunakan analisis statistik inferensial terdapat pengaruh self concept terhadap kemampuan berpikir tingkat tinggi siswa kelas VIII SMPN 1 Mataram tahun ajaran 2020/2021, dilihat melalui perhitungan uji F dan uji t. Hasil uji F diperoleh nilai $\mathrm{F}$ hitung sebesar 7,569 dan nilai $\mathrm{F}$ tabel pada taraf signifikan 5\% dengan derajat kebebasan pembilang (dk1) 1 dan penyebut (dk2) 30 adalah 4,17. Karena nilai $\mathrm{F}$ hitung $>\mathrm{F}$ tabel berarti koefisien regresi dari persamaan regresi $\mathrm{Y}=$ $1,283+0,787 \mathrm{X}$ dapat digunakan untuk memprediksi kemampuan berpikir tingkat tinggi yang ditinjau dari self concept. Persamaan regresi tersebut diartikan bahwa jika self concept siswa bertambah 1 satuan maka nilai kemampuan berpikir tingkat tinggi siswa bertambah sebesar 0,787; dan begitupun sebaliknya jika self concept siswa berkurang 1 satuan maka nilai kemampuan berpikir tingkat tinggi siswa berkurang sebesar 0,787. Selain itu, dari hasil perhitungan uji t diperoleh nilai t hitung sebesar 2,751 dan nilai t tabel pada taraf signifikansi $5 \%$ dengan derajat kebebasan dk $(\mathrm{N}-2)=$ 30 adalah 2,042. Karena $\mathrm{t}$ hitung $=2,751>\mathrm{t}$ tabel $=2,042$ maka koefisien korelasi sebesar 0,449 menunjukkan hubungan yang signifikan self concept terhadap kemampuan berpikir tingkat tinggi siswa kelas VIII SMPN 1 Mataram tahun ajaran $2020 / 2021$. 
Hasil perhitungan koefisien korelasi sebesar 0,449 juga dapat menentukan seberapa kuat hubungan self concept terhadap kemampuan berpikir tingkat tinggi siswa. Secara umum hubungan self concept terhadap kemampuan berpikir tingkat tinggi siswa kelas VIII SMPN 1 Mataram tahun ajaran 2020/2021 termasuk dalam tingkat hubungan yang cukup kuat, persentase besar pengaruh yang diberikan oleh self concept terhadap kemampuan berpikir tingkat tinggi siswa adalah 20,1\% yang berarti 79,9\% dipengaruhi oleh faktor lain. Hasil penelitian ini sejalan dengan penelitian yang dilakukan oleh (Abidah et al., 2020) yang menunjukkan adanya pengaruh dan hubungan yang kuat antara self concept dan kemampuan berpikir tingkat tinggi. Dapat diartikan bahwa self concept yang positif akan mempengaruhi kemampuan siswa untuk mempelajari matematika, sehingga tercapainya hasil belajar yang baik.

\section{SIMPULAN}

Dari hasil analisis statistik deskriptif self concept tersebut dapat disimpulkan bahwa secara umum sebagian besar siswa kelas VIII SMPN 1 Mataram memiliki self concept yang baik atau positif. Berdasarkan hasil analisis deskriptif dari kedua variabel, self concept siswa berbanding lurus dengan kemampuan tingkat tinggi, dimana kedua variabel dapat digolongkan dalam kategori baik yang mengindikasikan adanya hubungan antara kedua variabel. Berdasarkan hasil perhitungan menggunakan analisis statistik inferensial terdapat pengaruh self concept terhadap kemampuan berpikir tingkat tinggi siswa kelas VIII SMPN 1 Mataram tahun ajaran 2020/2021. Hasil perhitungan koefisien korelasi sebesar 0,449 juga dapat menentukan seberapa kuat hubungan self concept terhadap kemampuan berpikir tingkat tinggi siswa. Secara umum hubungan self concept terhadap kemampuan berpikir tingkat tinggi siswa kelas VIII SMPN 1 Mataram tahun ajaran 2020/2021 termasuk dalam tingkat hubungan yang cukup kuat, persentase besar pengaruh yang diberikan oleh self concept terhadap kemampuan berpikir tingkat tinggi siswa adalah 20,1\% yang berarti 79,9\% dipengaruhi oleh faktor lain.

\section{REFERENSI}

Abidah, R. Z., Kamsiyati, \& Anesa. (2020). Hubungan antara konsep diri dengan kemampuan berpikir tingkat tinggi sebagai transfer of knowledge materi pecahan pada peserta didik kelas V Sekolah Dasar. Jurnal Didaktika Dwija Indria, 8(1), 1-6.

Bransford, J. D., Ann L. Brown, A., \& Cocking, R. R. (2004). How people learn brain, mind, experience, and school. Washington: National Academy Press.

Gradini, E. (2019). Menilik konsep kemampuan berpikir tingkat tinggi (higher order thinking skills) dalam pembelajaran matematika. Jurnal Numeracy, 6(2), 189-203.

Kurniati, D., Harimukti, R., \& Jamil, N. A. (2016). Kemampuan berpikir tingkat tinggi siswa SMP di Kabupaten Jember dalam menyelesaikan soal berstandar PISA. Jurnal Penelitian Dan Evaluasi Pendidikan, 20(2), 142-155.

OECD. (2019). What 15-year-old students in Indonesia know and can do. Programme for International Student Assessment (PISA) Result from PISA 2018, I-III, 1-10.

Peraturan Menteri Pendidikan dan Kebudayaan Republik Indonesia Nomor 35 Tahun 2018 
Wahida et al Pengaruh self concept terhadap ...

tentang Perubahan Atas Peraturan Menteri Pendidikan dan Kebudayaan Nomor 58 tahun 2014 tentang Kurikulum 2013 Sekolah Menengah Pertama/Madrasah Tsanawiyah.

Rahman, R. (2012). Hubungan antara self-concept terhadap matematika dengan kemampuan berpikir kreatif matematik siswa. Jurnal Ilmiah Program Studi Matematika STKIP Siliwangi Bandung, 1(1), 19-30.

Sriyanti, L. (2009). Membentuk self concept positif pada anak (pendekatan parenting skill). Mudarrisa, 1(1), 16-35. 